\title{
Modern logistics technologies in the conditions of Slovak enterprises
}

\author{
Patrik Richnák ${ }^{1, *}$ \\ ${ }^{1}$ University of Economics in Bratislava, Department of Production Management and Logistics, \\ Dolnozemská cesta 1, 85235 Bratislava, Slovak Republic
}

\begin{abstract}
We are living in a time of technological progress, the development of new technologies and the digital transformation of industry. Customers continue to focus on product quality and enterprises are looking for solutions to reduce production costs, speed up and simplify the manufacturing process. One effective way to do this is to use modern logistics technology. The main aim of the paper was to examine logistics technologies used in Slovak enterprises. The intention of this paper was to analyse the issue under consideration the literary research and the survey, which was conducted in enterprises in Slovakia. To provide a comprehensive view, it was necessary to define terms and concepts in the first part of the paper - technology, logistics technology and types of logistics technologies. Subsequently, in the theoretical part of the paper we focused on the analysis of selected modern logistics technologies. From these we chose Efficient Consumer Response, Radio Frequency Identification and Quick Response. To provide a comprehensive view, we have selected modern logistics technologies under the conditions of Slovakia.
\end{abstract}

\section{Introduction}

Today's world is characterized by technical progress, development of new technologies, demanding requirements of customers who emphasize the quality of products. New global markets, business models, advances and innovations are emerging in every business area. This transformation will dramatically influence how organizations will be managed according to the new incentives, and environmental and context configuration [1]. Enterprises are looking for solutions to reduce costs in production and logistics, accelerate and simplify manufacturing and logistics processes. One effective way to achieve this is to use logistics technology.

In today's revolutionary conditions, logistics technologies are a prerequisite for efficient results in business management in the form of economy and efficiency. Their use and continuous improvement must be one of the necessary management activities in the enterprise. Nowadays we are witnessing a different theoretical understanding of logistics technologies and the use of a wide range of technologies by enterprises. In the paper, we first defined which are necessary to understand the issue. Subsequently, in the next part of

* Corresponding author: patrik.richnak@euba.sk 
the paper, we analysed selected modern logistics technologies on the basis of a literary research and through the survey we found their application and use in the Slovak enterprises.

\section{Literature review}

Modern technologies that reduce the need for jobs are part of everyday life and every society. Multinational companies are coming to the market to compete for global market share and to do anything to succeed. This is associated with a change in the economic integration regime throughout the world and the old markets will be transformed into new consumer markets. This implies that if a company wants to survive the current 21 st century, it needs to adapt quickly and flexibly to new conditions [2].

Lukoszová et al. characterizes technology as a sum of resources, which are used in production and service processes of the enterprise. It can be understood as a variety of means for a given job related to production, repair or service. Technology is also a collection of documents that contain trade secrets or know-how belonging to an enterprise, which may include plans, procedures, etc. [3].

Cejthamr and Dědina state that the technology contains various activities, machines, equipment, materials and experience used to perform work tasks. Technology can be found in a variety of forms, both in small and large enterprises, in the service sector, government institutions, manufacturing companies, international organizations and local small businesses. New technologies are created in the external environment of the company and can influence it in different ways. Technological development, which is represented by new knowledge and new techniques, can lead to a change in the company's existing production and other activities. It can also significantly affect the nature of the products or services provided by the organization [4].

Řezáč talks about management technologies that focus on the use of methods, approaches and management procedures to achieve corporate objectives. At the same time, they assume internal organization, sequence and harmonization of managerial activities. Managerial technologies can be divided into primary, which are related to material flow and its management processes and secondary, which are related to information flow and information cycle processes, also called digital technologies [5]. The next stage of evolution within these long-standing, leisurely-evolving technologies is here and the new generation of internal logistics is already knocking on the door, waiting to change logistics as we know it today. The revolution will mainly be possible thanks to the noticeably amplifying use of mobile robotic systems; modular, flexible and easily scalable automated logistics equipment; the ubiquitous IoT (Internet of Things) technologies allowing for flexible communication, real-time data transfer and big data analytics; and sophisticated, automated, agent-based control via cloud [6]. Logistics gains a greater vision in terms of mass adoption of smart and connected digital technologies and applications (e.g. mobile, cloud, sensors, data analytics, machine learning, blockchain, IoT) and enhancing vertical and horizontal integration among the supply chain partners [7].

Logistics technologies are understood to be the optimal arrangement of logistics operations into relatively stable processes. The logistics sequences that are created for the non-productive transformation of goods orders into their deliveries to customers do not guarantee optimal flexibility and economy in themselves. Therefore, using appropriate methods, these operations are organized as a whole so as to maximize the performance of the logistics system at a given cost level or to operate the logistics system at the lowest cost possible to achieve the desired performance [8].

Sixta and Žižka of the most important logistics technologies classified: Kanban, Just in Time, Quick Response, Efficient Consumer Response, Hub and Spoke, Cross-Docking, 
Warehouse Centralization and Network Concentration, Combined Transport, Automatic Identification, Computer Integrated Technologies in Manufacturing and Circulation and Communication Technologies [9].

In the logistical practice, a constantly growing range of technologies is applied, which are technologies that are shared by multiple disciplines and integrated into different concepts. The choice of appropriate logistics technologies depends on the level of the system or subsystem to which it is to be applied. The techno-technological subsystem includes classical logistics technologies (creation of handling groups, combined transport, Hub and Spoke, concentration of warehouse networks and centralization of warehouses); information and communication subsystems include telematic logistics technologies (automatic identification, radio frequency data communication, electronic data interchange and Internet, technology to support traffic fleet management); management subsystem includes virtual logistics technologies (simulations, graphical visualizations) and the multisystem includes complex logistics technologies (Just in Time, Kanban, Quick Response, Efficient Consumer Response) [10].

There are a couple of new challenges enterprises are facing to, such as changing economic conditions, coupled with decreasing trust in markets, increasing pressures on natural resources and significant changes in customer and employee demographics [11]. On account of that businesses will need to react to meet these new challenges in order to be successful. In our fast-moving world, the winners will be companies that can sense change and respond accordingly [12]. Now the fourth industrial revolution is coming, which can be called the digital revolution, dating back to the middle of the last century. It is characterized by a combination of technologies that eliminate the boundaries between the physical, digital and biological spheres [13]. Based on this fact, the current digital era brings changes and progress in logistics. If an enterprise wants to succeed in the era of digital technology, it must incorporate logistics technologies into the enterprise, which are a significant determinant of all sectors and logistics is no exception. Logistics technologies are rapidly evolving and become part of day-to-day business management by facilitating individual processes, increasing work efficiency and competitiveness of the enterprise. In the next part of the paper, selected modern logistics technologies, which are important and necessary for the proper functioning of business logistics, are discussed in the current digital revolution.

The Efficient Consumer Response (ECR) concept was introduced in 1992 as a result of competition from alternative store formats which highlighted major inefficiencies within the supermarket industry and its supply chain [14].

ECR has been defined more in the sense of a system or philosophy rather than a particular concept and stresses the complete vertical integration of the marketing channels [15].

The basis of formation of the ECR was the rapid development of information technologies, the ever growing competition, the formation and development of international trade organizations, as well as consumers' need for more qualitative, safer, fresher product with better service and broad assortment [16].

Automatic identification of objects has been very prominent in many fields mainly because of ease of use and high efficiency. Auto-ID includes bar codes, smart cards, biometrics and voice recognition, magnetic stripes, RFID, and numerous other devices. However, RFID has many benefits, especially over bar codes; RFIDs are non-line-of-sight and reusable, they can withstand harsh environments, and their high encryption prevents counterfeit [17].

The last decades have witnessed a rapid growth of RFID technology for identification and tracking because of its unique identification (UID). Besides this common usage, an analogue processing of the physical signals related to the reader-tag communication, could 
permit to achieve much more information about the target without the need for additional electronics or sensors [18].

Radio frequency identification (RFID) technology is based on wireless communication systems and offers easy integration into the Internet cloud system. The potential of RFID tag sensor technologies has been studied in different industrial sectors including healthcare, food safety, environmental pollution, anticounterfeiting of bank-notes and fake medicines, factories, customer shopping behavior, logistics, public transport, and safety [19].

Radio Frequency Identification is contactless communication is linked to barcodes. The carrier medium of information transmission are chips, which are either read or used to write data and read. RFID chips can be divided into two groups on active chips and passive chips. Passive chips are much cheaper and includes a power capacitor, which when capturing the electromagnetic pulses of the transmitter, uses the received energy to charge the capacitor and then send the answer. Passive chips transmit a number or have another memory into which they write or report more information. In addition, active chips have a power supply in addition to passive chips, so this chip can actively send information about itself and can be accurately searched for [20].

Huang et al. has of the opinion that a typical RFID system comprises of components: an active or passive tag which is a tiny programmable electronic circuit - that holds the Electronic Product Code (EPC) and other information to be transmitted; a tag reader which comprises of an antenna and transceiver which communicate with RFID tags and transfer the information to the processing devices [21].

RFID plays an important role in data acquisition systems, tracking of material flow on shop floors and through-out the distribution phase of the product. RFID when implemented in manufacturing firms, enables them achieve complex production system and to perform better life cycle assessment of their products [22].

The QR code is basically a two dimensional which takes matrix form with cell architecture in the form of a square. The QR consists of mainly two parts: function patterns and encoding region. The function pattern is usually not used encoding. The most commonly used encoding algorithm in the QR code is Reed-Solomon (RS) encoding technique [23].

Quick response codes are two-dimensional square patterns that enable the coding or storage of more than 7000 characters that can be accessed via a quick response code scanning application [24].

The quick response $(\mathrm{QR})$ supply chain system has received a great deal of attention in the recent past because of the advances in many new technologies such as RFID systems and mobile computing. Establishment of supply chain practices, such as collaborative planning, forecasting, and replenishment (CPFR), and vendor managed inventory (VMI) has also contributed to the development of QR in industrial practice [25].

Quick response strategy (QRS) has been widely adopted in a supply chain where members collect timely market information for better forecasting, and then respond promptly to the market changes by adjusting initial inventory decision [26].

\section{Research design}

The main aim of the paper was to examine logistics technologies used in Slovak enterprises. The intention of this paper was to analyse the issue under consideration the literary research and the survey, which was conducted in enterprises in Slovakia.

To provide a comprehensive view, it was necessary to define terms and concepts in the first part of the paper - technology, logistics technology and types of logistics technologies. Subsequently, in the theoretical part of the paper we focused on the analysis of selected modern logistics technologies. From these we chose Efficient Consumer 
Response, Radio Frequency Identification and Quick Response. To provide a comprehensive view, we have selected modern logistics technologies under the conditions of Slovakia. The research, which was conducted by questionnaire survey took part were small, medium-sized and large enterprises. The categorization of enterprises by size was based on the EU Commission Regulation no. 651/2014, where we considered as a small enterprise with a number of employees up to 50 and annual turnover up to EUR 10 million. As a medium-sized enterprise we considered the company with a number of employees up to 250 and an annual turnover of up to EUR 50 million. As large enterprise we considered the company with more than 250 employees and annual turnover of more than EUR 50 million.

We used system analysis and comparative analysis to process information and knowledge in the paper on the state and analysis of modern logistics technologies. We also used other classical methods such as: synthesis, induction and deduction. Among the specific methods we used the query, sorting method and visualization method.

\section{Research in the Slovak enterprises}

The research, which was conducted by questionnaire survey was attended by 150 enterprises. Figure 1 reveals that the Slovak enterprises make the most use of Efficient Consumer Response. The percentage of this technology is $19.3 \%$. The second most used logistics technology is Quick Response with a share of 12\%. Radio Frequency Identification is used by the Slovak enterprises with a share of $10.7 \%$. Modern logistics technologies are a big challenge and a financial burden for businesses, therefore we see in Figure 1 high percentages of non-use of logistics technologies - Radio Frequency Identification (58\%) and QR (48.7\%) by Slovak enterprises.

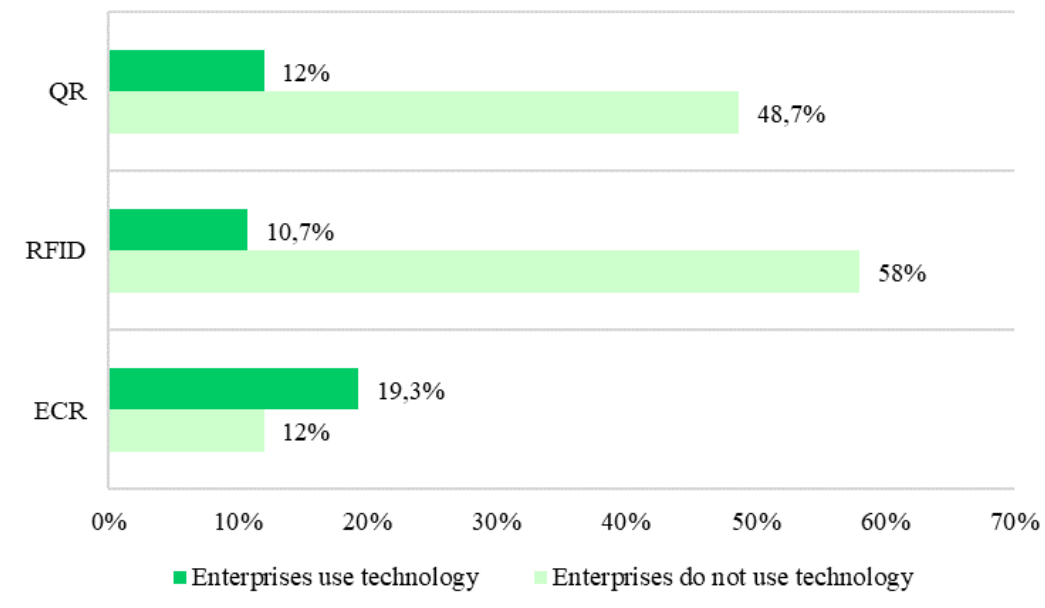

Fig. 1. Usage logistics technologies in Slovak enterprises. Source: own research

Figure 2 shows the use of selected modern logistics technologies according to business size. In large enterprises in Slovakia they use mainly Quick Response (60.7\%) and least Efficient Consumer Response (49.6\%). Efficient Consumer Response (42.2\%) is the most used in medium-sized enterprises and other logistics technologies differ by small percentages. Quick Response is used in medium-sized enterprises with a share of $31.6 \%$ and Radio Frequency Identification with a share of 31.2\%. Small enterprises are dominated 
by the use of Radio Frequency Identification (10.1\%) and the least are using Quick Response with a share of $7.7 \%$. When comparing selected logistics technologies according to business size, we can see a significant differentiation in the use of selected logistics technologies.

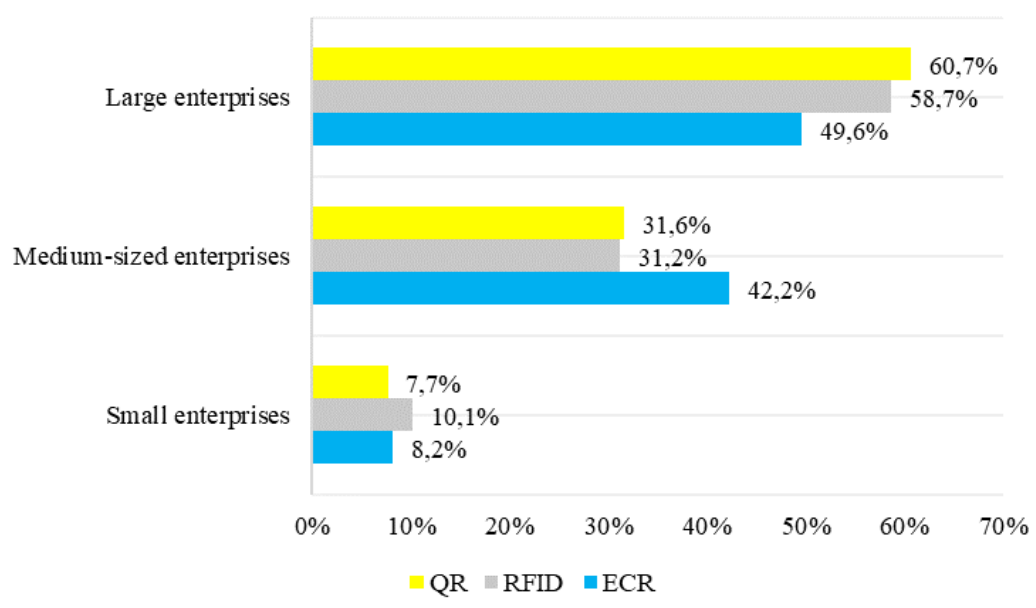

Fig. 2. Usage logistics technologies according to business size. Source: own research

Logistics technology - Efficient Consumer Response is used by enterprises mainly in distribution logistics. This part of business logistics achieved the largest percentage of 49.1\%. Enterprises use Efficient Consumer Response in procurement logistics with $38.8 \%$ share. The lowest percentage (12.1\%) of Efficient Consumer Response usage is in production logistics. Figure 3 shows the percentage.
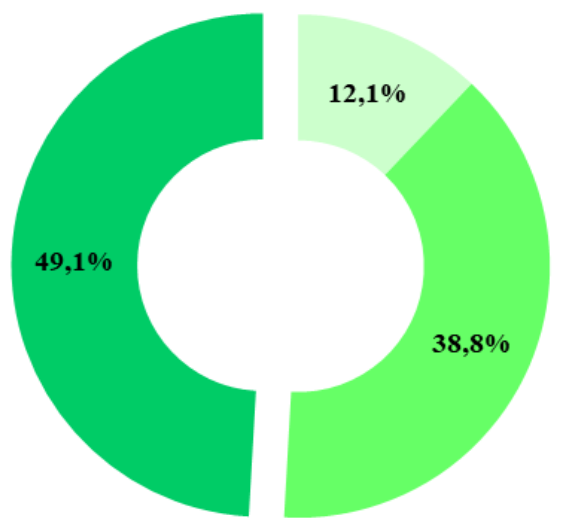

Production logistics $\quad$ Procurement logistics $\quad$ Distribution logistics

Fig. 3. Usage of ECR in business logistics fields. Source: own research

Figure 4 shows the percentage of usage of Radio Frequency Identification in business logistics of Slovak enterprises. The enterprises usage most Radio Frequency Identification in distribution logistics. The percentage is 53.6\%. Radio Frequency Identification is used 
by enterprises with a $36.6 \%$ share in procurement logistics. Radio Frequency Identification is the least used $(9.8 \%)$ in production logistics.

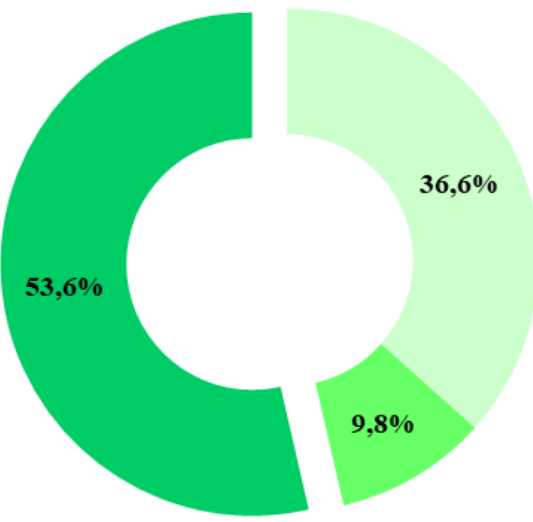

Production logistics $\quad$ Procurement logistics $\quad$ Distribution logistics

Fig. 4. Usage of RFID in business logistics fields. Source: own research

In Figure 5 we have the last selected logistics technology - Quick Response. The enterprises usage most of Quick Response in production logistics. Percentage achieved value $33.9 \%$. Quick Response is used by enterprises in procurement logistics with a share of $33.3 \%$. Quick Response is used in distribution logistics with a share of $32.8 \%$. The values obtained in this logistics technology are very similar. The percentages do not differ significantly from previous technologies.

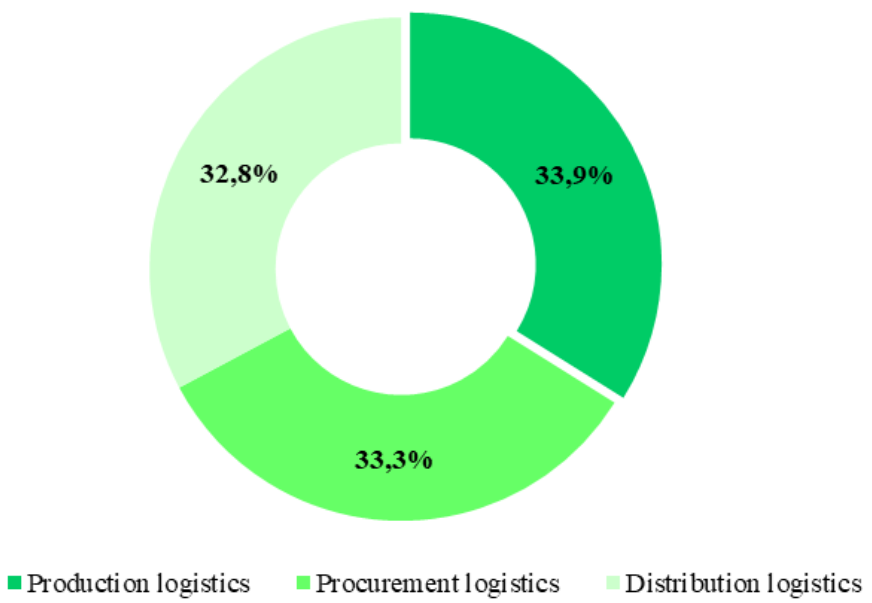

Fig. 5. Usage of QR in business logistics fields. Source: own research

Figure 6 shows the use of Efficient Consumer Response, Radio Frequency Identification and Quick Response in each type of industry. The radar graph was created based on the mean values. Efficient Consumer Response is the most widely used (4.2) in electrical engineering industry. Efficient Consumer Response also recorded a high mean usage in construction industry (3.9) and the automotive industry (3.4). The lowest mean 
value (1.4) of this technology was recorded in chemical industry. Radio Frequency Identification is the most used in automotive industry (2.0). The use of Radio Frequency Identification is recorded a high mean in electrical engineering industry (1.9). The lowest mean value (0) was recorded in textile industry. Quick Response is the most used in food industry (2.6). The lowest mean value (0) was recorded in glass industry.

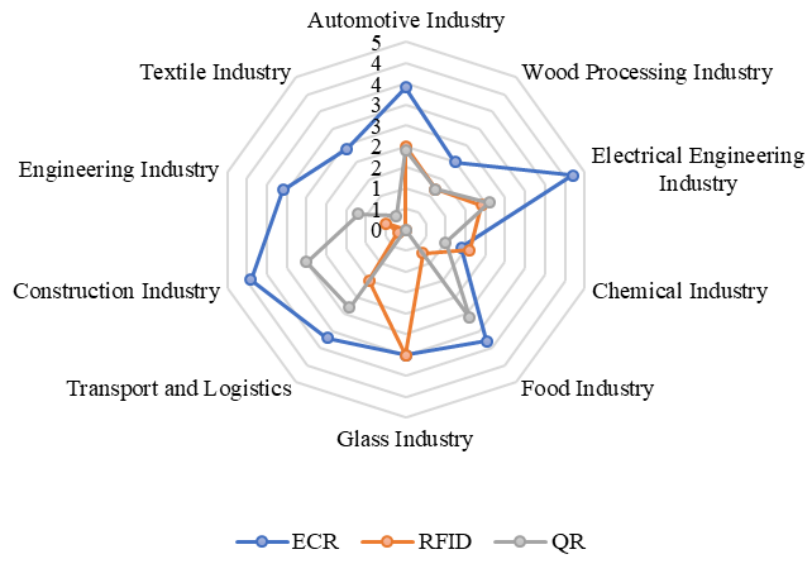

Fig. 6. Usage of logistics technologies in enterprises by types of business industries. Source: own research

Figure 7 shows the use of Efficient Consumer Response, Radio Frequency Identification and Quick Response in enterprises by regions in Slovakia. The radar graph was created based on the mean values. Efficient Consumer Response is mostly used in enterprises in Prešov Region. The mean value achieved 4.0. The enterprises in Bratislava, Trnava and Trenčín Regions obtained a higher mean values (3.8) in the use Efficient Consumer Response. The lowest mean value (3.1) of Efficient Consumer Response was recorded in Žilina Region. Radio Frequency Identification is the most used in enterprises in Bratislava Region. The mean value achieved 2.1. Prešov Region (1.8), Banská Bystrica Region (1.5) and Trnava Region (1.5) recorded balanced mean values. The lowest mean value (0.6) of Radio Frequency Identification was recorded in enterprises of Žilina Region. Quick Response is the most used in enterprises in Bratislava Region. The mean value achieved 3.1. The lowest mean value (0.9) of Quick Response was recorded in enterprises of Žilina Region. 


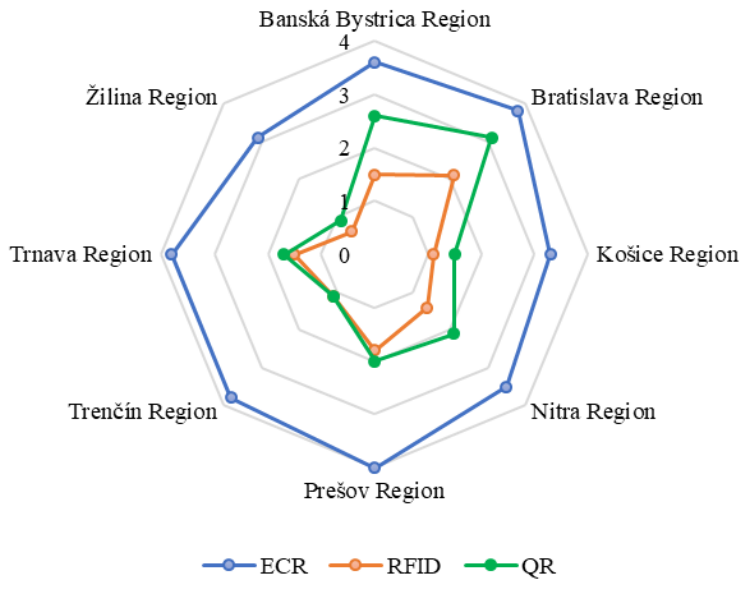

Fig. 7. Usage of logistics technologies in enterprises by regions of Slovakia. Source: own research

\section{Conclusion}

Nowadays, if companies want to stay at the forefront of the market and meet the needs and wishes of their customers, they need to be flexible, so they can adapt their business processes to demand [27]. This is the reason why the company seeks to create a competitive advantage over other producers and service providers [28].

New technologies fundamentally change the way businesses operate and develop their business, bringing new challenges to IT managers. How successfully the company will adapt to the digital transformation will be directly related to its competitiveness and future market survival [29]. Today, we use new technologies (Internet, self-service systems) to reduce service jobs [30].

The main aim of the paper was to examine logistics technologies used in Slovak enterprises. The intention of this paper was to analyse the issue under consideration the literary research and the survey, which was conducted in enterprises in Slovakia.

The surveyed Slovak enterprises from modern logistics technologies make the most use of Efficient Consumer Response with a share of $19.3 \%$.Of the selected logistics technologies analyzed, companies do not use Radio Frequency Identification with a share of 58\%. In large enterprises in Slovakia they use mainly Quick Response (60.7\%). Efficient Consumer Response $(42.2 \%)$ is the most used in medium-sized enterprises. Small enterprises are dominated by the use of Radio Frequency Identification (10.1\%). Logistics technology - Efficient Consumer Response is used by enterprises mainly in distribution logistics. The enterprises usage most of Quick Response in production logistics. . Efficient Consumer Response is the most widely used (4.2) in electrical engineering industry. Radio Frequency Identification is the most used in automotive industry (2.0). Quick Response is the most used in food industry (2.6). Efficient Consumer Response is mostly used in enterprises in Prešov Region. Radio Frequency Identification is the most used in enterprises in Bratislava Region. Quick Response is the most used in enterprises in Bratislava Region.

\section{Acknowledgments}


The article is a partial output of research project VEGA No. 1/0375/20 „New dimension in the development of production management and logistics under the influence of Industry 4.0 in enterprises in Slovakia“. 


\section{References}

1. L. Barreto, A. Amaral, T. Pereira, Industry 4.0 implications in logistics: an overview. Procedia Manufacturing, 13, 1245-1252 (2017)

2. J. Sixta, V. Mačát, Logistika : teorie a praxe (CP Books, 2005)

3. X. Lukoszová, a kol., Logistické technologie v dodavatelském řetězci. (Ekopress, 2012)

4. V. Cejthamr, J. Dědina, Management a organizační chování. (Grada Publishing, 2010)

5. J. Řezáč, Moderni management: manažer pro 21. století. (Computer Press, 2009)

6. T. Gregor, M. Krajčovič, D. Więcek, Smart Connected Logistics. Procedia Engineering, 192, 265-270 (2017)

7. Y. Kayikci, Sustainability impact of digitization in logistics. Procedia Manufacturing, 21, 782-789 (2018)

8. V. Cempírek, R. Kampf, J. Široký, Logistické a přepravní technologie. (Institut Jana Pernera, 2009)

9. J. Sixta, M. Žižka, Logistika: metody použivané pro řě̌ení logistických projektů (CP Books, 2009)

10. P. Pernica, Logistika pro 21. století : supply chain management. (RADIX, 2005)

11. A. Čambalíková, Agile way of working and its impact on business performance. Edamba 2017: International Scientific Conference For Doctoral Students And Post-Doctoral Scholars: University Of Economics In Bratislava, Slovak Republic, 4 - 6 April 2017, 52-59 (2017)

12. A. Cambalíková, L'. Szabo, Modern trends in management and their application in controlling. Socio-Economic Perspectives In The Age Of Xxi Century Globalization: Proceedings Book: International Conference: Tirana, December 1-2, 2017, 475-488 (2017)

13. J. Rakovská, Využitie Industry 4.0 vo výrobe a logistike na Slovensku. Nová dimenzia logistiky v štvrtej priemyselnej revolúcii v podnikoch na Slovensku: Zborník vedeckých statí, 90-98 (2019)

14. K. S. Bhutta, F. Huq, F. Maubourguet, Efficient Consumer Response - Increasing Efficiency through Cooperation. Cost Management in Supply Chains, 195-212 (2002)

15. G. Svensson, Efficient consumer response - its origin and evolution in the history of marketing', Management Decision, 40, 5, 508-519 (2002)

16. Y. Kato, R. Kiriyama, T. Takenaka, Y. Kurisu, D. Nozaki, K. Yano, F. Sato, T. Iida, Enhanced production of ECR plasma by using pulse mode microwaves on a large bore ECRIS with permanent magnets. Source: 19. international conference on ion implantation technology (2012)

17. E. C. Jones, B. Gray, M. Wijemanne, J. Bolton, Tracked: What You Should Know about RFID, Big Data, The Internet of Things, and Data Security (PWD Group Press, 2015)

18. C. Occhiuzzi, S. Caizzone, G. Marrocco, Passive UHF RFID antennas for sensing applications: Principles, methods, and classifcations. IEEE Antennas Propag. 55, 14 34 (2013)

19. R. Singh, E. Singh, H. S. Nalwa, Inkjet printed nanomaterial based flexible radio frequency identification (RFID) tag sensors for the internet of nano things. RSC $A d v ., 7,77,48597-48630$ (2017) 
20. W. Macdougall, Industrie 4.0: Smart Manufacturing for the Future, (Germany Trade \& Invest, 2014)

21. Y. Huang, B. C. Williams, L : Zheng, Reactive, model-based monitoring in RFIDenabled manufacturing. Computers in Industry, 62, 811-819 (2011)

22. A. M. Fet, D. Margrethe Aspen, H. Ellingsen, Systems engineering as a holistic approach to life cycledesigns. Ocean Engineering, 62, 1-9 (2013)

23. S. Nishane, V. M. Umale, Digital image watermarking based on DWT using QR code, International Journal of Current Engineering and Technology, 5, 3, 1530-1532 (2015)

24. J. Zurmehly, K. Adams, Using Quick Response Codes in the Classroom. CIN: Computers, Informatics, Nursing, 35, 10, 505-511 (2017)

25. T.M. Choi, S. Sethi, Innovative Quick Response Programs: A Review. International Journal of Production Economics, 127, 1, 1-12 (2010)

26. H-L. Chan, B. Shen, Y. Cai, Quick response strategy with cleaner technology in a supply chain: coordination and win-win situation analysis. International Journal of Production Research, 56,10, 3397-3408 (2017)

27. K. Porubanová, N. Púčková, Technologické prínosy ekonomickej analýzy výrobného procesu podniku: Technological Benefits of Economic Analysis of the Production Process. Nová dimenzia logistiky $v$ štvrtej priemyselnej revolúcii $v$ podnikoch na Slovensku: Zbornik vedeckých statí, 67-81 (2019)

28. D. Klátiková, K. Gubová, Kvalita elektronickej služby ako faktor zabezpečenia konkurencieschopnosti podniku. Manažment podnikania a vecí verejných - Dialógy: vedecko-odborný časopis Slovenskej Akadémie Manažmentu, 10, 30, 97-107 (2015)

29. A. Čambalíková, Využitie manažérskych nástrojov Big Data Analytics a Digital Transformation. Manažment informačnej bezpečnosti v malých a stredných podnikoch: Zbornik vedeckých statí, 35-41 (2015)

30. J. Rakovská, Podnikanie ako poslanie. Marketing Identity 2013: Zborník z medzinárodnej vedeckej konferencie 4. - 5. November 2013, Smolenice, 351-358 (2013) 